Rev. Int. Contam. Ambie. 37, 373-387, 2021

https://doi.org/10.20937/RICA.53781

\title{
BIOAVAILABLE AND TOTAL COPPER AND LEAD IN TERRIGENOUS SEDIMENTS IN THE INNER CONTINENTAL SHELF OFF VERACRUZ, SOUTHERN GULF OF MEXICO
}

Cobre y plomo biodisponible y total en sedimentos terrigenos de la plataforma continental interna frente a Veracruz, sur del Golfo de México

\author{
Guillermo HORTA-PUGA ${ }^{1 *}$, Rafael Andrés CABRAL-TENA ${ }^{1,2}$, Alejandro CÓRDOVA ${ }^{1}$, \\ Jhoan GUTIÉRREZ-MARTÍNEZ ${ }^{1}$, Francisco LÓPEZ-GALINDO ${ }^{1}$, \\ Aura Aletse MORALES-ARANDA ${ }^{1}$ and Alfonso SOLER-ABURTO ${ }^{1}$
}

\footnotetext{
${ }^{1}$ Unidad de Biotecnología y Prototipos (UBIPRO), Facultad de Estudios Superiores Iztacala, Universidad Nacional Autónoma de México, Av. de los Barrios 1, Los Reyes Iztacala, 54090 Tlalnepantla, Estado de México, México.

${ }^{2}$ Departamento de Ecología Marina, Centro de Investigación Científica y Educación Superior de Ensenada (CICESE), Carretera Ensenada-Tijuana 3918, Zona Playitas, 22860 Ensenada, Baja California, México.
}

*Corresponding author: horta@unam.mx

(Received: October 2019; accepted: July 2020)

Key words: trace elements, contamination, environmental quality.

\begin{abstract}
The inner continental shelf adjacent to the city and port of Veracruz (ICSV) in the southern Gulf of Mexico, which is influenced by the Jamapa River, has been considered to be polluted. Moderate to high $\mathrm{Cu}$ and $\mathrm{Pb}$ concentrations have previously been reported in the shelf's terrigenous sediments. These elements are derived from deposition of materials from mainland sources via river transport and may threaten marine life in the coastal area. Because $\mathrm{Cu}$ and $\mathrm{Pb}$ bioavailability has not been previously assessed in the region, the aim of this study was to determine $(i)$ bioavailability and total concentrations of these elements in the terrigenous sediments of the ICSV, (ii) if concentrations of these elements in sediments are associated with distances from primary sources, and (iii) if concentrations differ during dry and rainy seasons. Bioavailable general average concentrations were $0.21 \mu \mathrm{g} / \mathrm{g}$ for $\mathrm{Cu}$, and $0.24 \mu \mathrm{g} / \mathrm{g}$ for $\mathrm{Pb}$, which accounted for 4.4-4.9\% of the total content. The bioavailable concentrations were higher during the rainy season, and in the fluvial plume of the Jamapa River. The total content of $\mathrm{Cu}$ and $\mathrm{Pb}$ was significantly associated with fine sediments and exhibited high concentrations in the new port facilities area. Hence, it is concluded that the Jamapa River is a primary source of trace metals to the ICSV. Finally, as concentrations of trace metals are lower than previous records for sediments in the southern Gulf of Mexico and lower than background levels and maximum permissible limits, the ICSV is presently not contaminated by $\mathrm{Cu}$ or $\mathrm{Pb}$.
\end{abstract}

Palabras clave: elementos traza, contaminación, calidad ambiental. 


\section{RESUMEN}

Se ha considerado que la plataforma continental interna ubicada frente a la ciudad y puerto de Veracruz (PCIV), al sur del Golfo de México, la cual recibe la influencia del río Jamapa, está contaminada. Se han reportado concentraciones moderadas a altas de $\mathrm{Cu}$ y $\mathrm{Pb}$ en los sedimentos terrígenos de la plataforma continental que llegan desde el continente por transporte fluvial, amenazando la vida marina de la zona costera. Sin embargo, hasta ahora la biosdisponibilidad de $\mathrm{Cu}$ y $\mathrm{Pb}$ no ha sido evaluada. El objetivo de este estudio fue determinar la concentración total y biodisponible de dichos metales en sedimentos terrígenos en la PCIV, así como la variabilidad asociada a la distancia de las fuentes principales y la variabilidad estacional (temporada seca y de lluvias), para evaluar si el PCIV está contaminado. La concentración promedio general biodisponible fue de 0.21 y $0.23 \mu \mathrm{g} / \mathrm{g}$ para para $\mathrm{Cu}$ y $\mathrm{Pb}$, respectivamente, lo que constituye el 4.4-4.9\% del contenido total. Las concentraciones en fase biodisponible fueron más altas durante la temporada de lluvias y en la pluma fluvial del río Jamapa. El contenido total de $\mathrm{Cu}$ y $\mathrm{Pb}$ se correlacionó significativamente con los sedimentos finos, y ambos presentaron concentraciones más altas en el área cercana a las nuevas instalaciones portuarias. Por lo tanto, se considera que el río Jamapa es una fuente de metales traza en el PCIV. Finalmente, dado que la concentración de metales traza es baja, comparada con los registros previos en el sur de Golfo de México, y más baja que los niveles base y máximos permisibles, la PCIV no puede considerarse como un área contaminada por $\mathrm{Cu}$ y $\mathrm{Pb}$.

\section{INTRODUCTION}

Marine sediments in coastal areas and the inner continental shelves are largely influenced by river discharge. They are generally composed of finegrained siliciclastic sediments (up to $95 \%$ of the total volume of sediments) which were formed during weathering of continental rocks and transported in suspension by rivers into the ocean (Milliman et al. 1995, Kasper-Zubillaga et al. 1999, Vázquez et al. 2002, Walling 2006, Rosales-Hoz et al. 2015). Along with particulate organic carbon from land vegetation, these terrigenous sediments are an important source of trace elements (Martin and Whitfield 1983, Milliman and Meade 1983, Dupré et al. 1996, Rosales-Hoz et al. 2005). Rivers receive municipal, agricultural and industrial sewage waters, which contain several anthropogenic pollutants, including trace elements (Dassenakis et al. 1997, Kaushik et al. 2009, RuizFernández et al. 2012). Coastal development is also a cause of trace elements contamination of adjacent continental shelves via urban runoff, discharge of untreated sewage waters, and port, shipping and fishing activities (Wang et al. 2013). Hence, high concentrations of trace metals are expected to be found in coastal areas and inner continental shelves that are located near both urban areas and river outlets.

The inner continental shelf adjacent to the city and port of Veracruz (ICSV) in the southern Gulf of Mexico is an area highly influenced by the Jamapa
River and the city of Veracruz. The river drains an area of $\sim 4061 \mathrm{~km}^{2}$, wherein $>70 \%$ of the land is used for agriculture and raising cattle. During rainy seasons (June to October), the Jamapa River discharges higher volumes of freshwater (that are caused by higher precipitation rates) than in dry seasons (March-May) and seasons associated with northerly cold-fronts (November-February) (Gutiérrez-de Velasco and Winant 1996, Carrillo et al. 2007, Avendaño-Álvarez et al. 2017). During rainy seasons, higher soil erosion rates enhance mobilization of fine terrigenous siliciclastic sediments up to $32 \mathrm{mg} / \mathrm{L}$ (Carriquiry and Horta-Puga 2010, Horta-Puga et al. 2015, Horta-Puga 2017), which are a natural source of lattice-bound $\mathrm{Cu}$ and $\mathrm{Pb}$ in the ICSV (Morelock and Koenig 1967, Horta-Puga 2007, Rosales-Hoz et al. 2007). The cities of Córdoba and Veracruz and their industrial areas also discharge sewage waters into the Jamapa River which contribute additional sources of pollutants that may also reach the ICSV (Horta-Puga et al. 2013, Horta-Puga and Carriquiry 2014, Cabral-Tena et al. 2019). Veracruz is a large, populated (> 800000 inhabitants) and industrialized city. It is an important tourist destination and cargo port, and is considered to be a non-point source of pollutants in the local marine environment (Rosales-Hoz et al. 2007, Celis-Hernández et al. 2013, 2017, Horta-Puga et al. 2013). Hence, the ICSV has been considered to be a polluted coastal area (Tunnell 1992, Villanueva and Botello 1992, Horta-Puga, 2007, Ortiz-Lozano 2012). 
Trace metal concentrations have been recorded in various environmental compartments in the ICSV, like reef corals (Carriquiry and Horta-Puga 2010, Horta-Puga and Carriquiry 2014), reef benthic macroalgae (Horta-Puga et al. 2013, 2014), surface seawater (Rosales-Hoz et al. 2009), inter-reef sediments (Rosales-Hoz et al. 2007, Celis-Hernández et al. 2013, 2017), and bioclastic reef sediments (Horta-Puga 2017). These studies report high concentrations of $\mathrm{Cu}$ derived from the use of anti-fouling paints (Horta-Puga et al. 2013), and presence of $\mathrm{Cu}$ and $\mathrm{Pb}$ from non-point sources associated with port activities and/or river influence (Rosales-Hoz et al. 2007, Celis-Hernández et al. 2013, 2017, Horta-Puga and Carriquiry 2014, Horta-Puga 2017). Horta-Puga and Carriquiry (2014) also demonstrate that aerosols released to the atmosphere during mining and processing of $\mathrm{Pb}$ ores in northern regions of the USA and combustion of alkyl-lead gasolines in Mexico were important sources of $\mathrm{Pb}$ in the ICSV. The transport of barite $\left(\mathrm{BaSO}_{4}\right)$, a material used as drilling mud in oil extraction platforms, by ocean currents in the northern Gulf of Mexico is a source of Ba in the ICSV (Carriquiry and Horta Puga 2010). These observations suggest that trace elements released by natural (Self 1977, Kasper-Zubillaga and Carranza-Edwards 2003, Armstrong-Altrin and Natalhy-Pineda 2013) or anthropogenic processes in the open waters of the Gulf of Mexico also may reach the ICSV. However, only $\mathrm{Cu}$ has so far presented a high enrichment factor in sediments from the ICSV (Celis et al. 2013, 2017).

Given that elements that are bounded to the bioavailable fraction of sediments might cause deleterious effects on organisms (Tessier and Campbell 1987, Luoma 1989), it is important to know how trace metals like $\mathrm{Cu}$ and $\mathrm{Pb}$ are associated with the bioavailable fraction of sediments in the ICSV. The primary aim of this study was to determine the bioavailable and total concentrations of $\mathrm{Cu}$ and $\mathrm{Pb}$ in the terrigenous sediments of the ICSV. Additional aims were to characterize the spatial variability of $\mathrm{Cu}$ and $\mathrm{Pb}$ concentrations and determine if they are associated with distance from the main known sources (Veracruz city and Jamapa River) as well as the differential influence of the Jamapa River during dry and rainy seasons.

\section{MATERIALS AND METHODS}

\section{Study area and sampling design}

The study area comprises the inner continental shelf $(<50 \mathrm{~m}$ depth) adjacent to the city of Veracruz in the southern Gulf of Mexico (Fig. 1) and includes the Veracruz Reef System (VRS), the largest reef ecosystem in the Gulf of Mexico (Carricart-Ganivet and Horta-Puga 1993, Tunnell 2007, Horta-Puga et al. 2015). As the aim of this study was to determine trace metal concentrations of terrigenous sediments, and not those in reef sediments which are composed mainly by calcareous bioclasts (Emery 1963, Morelock and Koenig 1967, Horta-Puga 2017), 22 sampling stations were chosen which encompass the environmental variability of the inner shelf. Stations were positioned at inter-reef zones and at different distances from the coastline and mouth of the Jamapa River (Table I). Sediment samples were collected in 2016 during dry (April 18-23) and rainy (October 6-9) seasons. We also divided stations based on location relative to the outlet of the Jamapa River that included northern stations (GN), southern ones (GS), and stations in the river outlet (OJ). These two areas are potentially subject to different inputs of trace elements, considering that surface currents might transport them to the north from the outlet of the Jamapa River during rainy seasons (Zavala-Hidalgo et al. 2003, Carrillo et al. 2007, Carriquiry and Horta-Puga 2010). Also, we expected to find differences between nearshore (NS) and offshore (OS) areas, considering that nearshore areas $(<1 \mathrm{~km}$ from shore $)$ are subject to a higher influence from human activities that take place in coastal areas (see Table I for details on the stations that comprise each group).

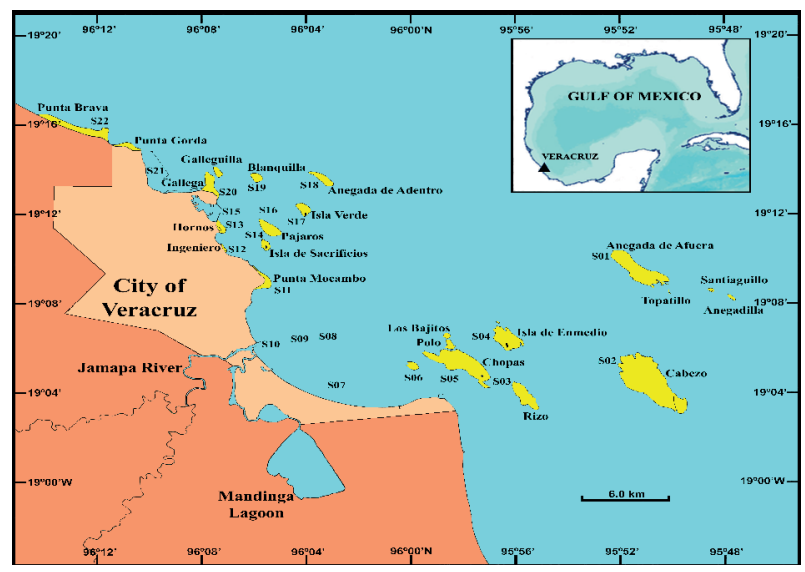

Fig. 1. Inner continental shelf adjacent to the city of Veracruz in the southern Gulf of Mexico (ICSV). The emergent reefs of the Veracruz Reef System (VRS) and positions of sediment sampling stations are shown with their codes.

\section{Sediment collection and treatment}

Samples of terrigenous surface sediments $(\sim 500 \mathrm{~g})$ were collected using a van Veen grab that was operated manually from a small boat, placed in acid 
TABLE I. SEDIMENT SAMPLING STATIONS IN THE INNER CONTINENTAL SHELF OF VERACRUZ

\begin{tabular}{|c|c|c|c|c|c|}
\hline Stations & Depth (m) & Lat. $\mathrm{N}$ & Long. W & Group & RDFS \\
\hline S01 & 24 & $19^{\circ} 09^{\prime} 56.7 ”$ & $95^{\circ} 52^{\prime} 17.4 "$ & GS & OS \\
\hline S02 & 24 & $19^{\circ} 05^{\prime} 24.5^{\prime \prime}$ & $95^{\circ} 56^{\prime} 12.8^{\prime \prime}$ & GS & OS \\
\hline S03 & 21 & $19^{\circ} 04^{\prime} 31.7^{\prime \prime}$ & $95^{\circ} 56^{\prime} 12.8^{\prime \prime}$ & GS & OS \\
\hline S04 & 21 & $19^{\circ} 06^{\prime} 31.6^{\prime \prime}$ & $95^{\circ} 57^{\prime} 15.0^{\prime \prime}$ & GS & OS \\
\hline S05 & 14 & $19^{\circ} 04^{\prime} 37.9^{\prime \prime}$ & $95^{\circ} 58^{\prime} 18.3$ & GS & OS \\
\hline S06 & 19 & $19^{\circ} 04^{\prime} 37.9^{\prime \prime}$ & $95^{\circ} 59^{\prime} 46.1^{\prime \prime}$ & GS & OS \\
\hline S07 & 15 & $19^{\circ} 04^{\prime} 29.8^{\prime \prime}$ & $96^{\circ} 02^{\prime} 38.3^{\prime \prime}$ & GS & NS \\
\hline S08 & 22 & $19^{\circ} 06^{\prime} 19.6^{\prime \prime}$ & $96^{\circ} 03 ' 14.1^{\prime \prime}$ & $\mathrm{OJ}$ & RI \\
\hline S09 & 15 & $19^{\circ} 06^{\prime} 12.7^{\prime \prime}$ & $96^{\circ} 04^{\prime} 33.4^{\prime \prime}$ & $\mathrm{OJ}$ & RI \\
\hline $\mathrm{S} 10$ & 7 & $19^{\circ} 06^{\prime} 11.9^{\prime \prime}$ & $96^{\circ} 05^{\prime} 32.4^{\prime \prime}$ & $\mathrm{OJ}$ & RI \\
\hline $\mathrm{S} 11$ & 10 & $19^{\circ} 09^{\prime} 05.8^{\prime \prime}$ & $96^{\circ} 05^{\prime} 11.1^{\prime \prime}$ & GN & NS \\
\hline S12 & 7 & $19^{\circ} 10^{\prime} 30.7^{\prime \prime}$ & $96^{\circ} 06^{\prime} 51.8^{\prime \prime}$ & GN & NS \\
\hline $\mathrm{S} 13$ & 11 & $19^{\circ} 11^{\prime} 30.0 "$ & $96^{\circ} 06^{\prime} 50.8^{\prime \prime}$ & GN & NS \\
\hline S14 & 5 & $19^{\circ} 11^{\prime} 17.8^{\prime \prime}$ & $96^{\circ} 05^{\prime} 51.5^{\prime \prime}$ & GN & OS \\
\hline $\mathrm{S} 15$ & 15 & $19^{\circ} 12^{\prime} 01.6 "$ & $96^{\circ} 06^{\prime} 46.8^{\prime \prime}$ & GN & NS \\
\hline S16 & 22 & $19^{\circ} 11^{\prime} 57.5^{\prime \prime}$ & $96^{\circ} 04^{\prime} 55.7^{\prime \prime}$ & GN & OS \\
\hline $\mathrm{S} 17$ & 24 & $19^{\circ} 11 ' 59.6 "$ & $96^{\circ} 04^{\prime} 22.9^{\prime \prime}$ & GN & OS \\
\hline S18 & 30 & $19^{\circ} 13^{\prime} 25.7$ & $96^{\circ} 03$ '32.4”' & GN & OS \\
\hline $\mathrm{S} 19$ & 20 & $19^{\circ} 13^{\prime} 22.7 "$ & $96^{\circ} 06^{\prime} 00.0^{\prime \prime}$ & GN & OS \\
\hline $\mathrm{S} 20$ & 18 & $19^{\circ} 13$ ' 16.9”' & $96^{\circ} 07^{\prime} 03.8^{\prime \prime}$ & GN & NS \\
\hline $\mathrm{S} 21$ & 12 & $19^{\circ} 13^{\prime} 54.5^{\prime \prime}$ & $96^{\circ} 09^{\prime} 25.1^{\prime \prime}$ & GN & NS \\
\hline $\mathrm{S} 22$ & 5 & $19^{\circ} 05^{\prime} 30.4^{\prime \prime}$ & $96^{\circ} 11^{\prime} 25.8^{\prime \prime}$ & GN & NS \\
\hline
\end{tabular}

GS: southern group, GN: northern group, OJ: Jamapa oulet group, RDFS: relative distance from shore, OS: offshore, NS: nearshore, RI: river influenced

pre-cleaned $\left(2 \% \mathrm{HNO}_{3}\right)$ plastic bags, and transported in a cooler with dry ice. In the laboratory, sample aliquots $(20 \mathrm{~g})$ were oven-dried $\left(60^{\circ} \mathrm{C}, 48 \mathrm{~h}\right)$, homogenized, and sieved $(<2 \mathrm{~mm})$. Afterwards, samples were rinsed with deionized water $(40 \mathrm{ml})$, agitated (15 min, $120 \mathrm{rpm}$ ), and centrifuged in polypropylene tubes (10000 rpm, $45 \mathrm{~min}$ ), discarding the supernatants and repeating the rinsing process, to eliminate precipitated seawater salts. Then, samples were once again oven-dried and stored in clean low density polyethylene containers (Horta-Puga 2017). The bioavailable fraction (i.e., all elements in geochemical fractions that could be incorporated by organisms) was extracted from $3 \mathrm{~g}$ aliquots with $1 \mathrm{M} \mathrm{HNO}_{3}(30 \mathrm{ml})$, agitated $(2 \mathrm{~h}, 120 \mathrm{rpm})$, filtered (Whatman 42) to eliminate the remaining sediment particles, and stored until instrumental analysis (Soon and Abboud 1993, Cabral-Tena et al. 2019). For the determination of the total content of $\mathrm{Cu}$ and $\mathrm{Pb}, 0.5 \mathrm{~g}$ aliquots were digested (at $130{ }^{\circ} \mathrm{C}$ and 10.3 Bar for $45 \mathrm{~min}$ ) in a microwave oven (CEM MDS 2100), with a $10 \mathrm{ml}$ mixture of minerals acids $\left(\mathrm{HNO}_{3}: \mathrm{HF}: \mathrm{HCl}\right.$, $5: 4: 1, \mathrm{~V} / \mathrm{V} / \mathrm{V})$. Then, $2 \mathrm{~g}$ of $\mathrm{H}_{3} \mathrm{BO}_{3}$ were added to each digested sample, brought up to a final weight of $\sim 25 \mathrm{~g}$ with $2 \% \mathrm{HNO}_{3}$, and stored until analysis
(Cabral-Tena et al. 2019). Grain size distribution (GSD) of samples (sand, silt and clay fractions) were determined by the standard hydrometer method (Sheldrick and Wang 2000), and organic carbon content (OC) was determined by the modified Walkey and Black titration method (Walkey and Black 1934, De Vos et al. 2007).

\section{Instrumental analysis}

Concentrations of $\mathrm{Cu}$ and $\mathrm{Pb}$ were determined by atomic absorption spectroscopy (GFAAS, Varian SpectrAA 800). Only high purity stock solutions $(1000 \mu \mathrm{g} / 1)$ that were diluted with $2 \% \mathrm{HNO}_{3}$ were used for instrument calibration. Quantification limits (LOQ) were calculated using dilution factors and the concentration of lowest standard solutions used for instrument calibration. Values for the bioavailable fraction were $\mathrm{LOQ}_{\mathrm{CuBio}}=0.05 \mu \mathrm{g} / \mathrm{g}$, and $\mathrm{LOQ}_{\mathrm{PbBio}}=$ $0.02 \mu \mathrm{g} / \mathrm{g}$; and for the total concentration LOQ $\mathrm{CuTot}$ $=0.25 \mu \mathrm{g} / \mathrm{g}$, and LOQPbTot $=0.1 \mu \mathrm{g} / \mathrm{g}$. Instrument precision, determined from several measurements of a standard solution between samples during analytical runs, was $4.4 \%$ for $\mathrm{Cu}$ and $4.3 \%$ for $\mathrm{Pb}$. Reference material (NIST, SRM 2072, Baltimore Harbor Marine Sediment) was used to determine analytical accuracy, 
and metal recovery was $106.6 \%$ for $\mathrm{Cu}$, and $105.4 \%$ for $\mathrm{Pb}$. The preparation of solutions, standards, and chemical treatment of samples were performed in a clean laboratory Class 100 . Results are reported in $\mu \mathrm{g} / \mathrm{g}$ (dry weight). It is important to mention that the treatment and chemical analysis of samples was performed simultaneously with the processing of fluvial sediment samples of the Jamapa River for which data are already published (Cabral-Tena et al. 2019).

\section{Statistical analyses}

Paired t-tests and/or Mann-Whitney tests were used to determine differences between seasons (DS vs. RS), groups of reefs (GN vs. GS), and distance from shore (NS vs. OS). Pearson's correlation was also used to assess the association between sediment physicochemical parameters. All statistical analyses were performed using the Past v. 3.24 software (Hammer et al. 2001).

\section{RESULTS}

\section{Geochemical characterization of sediments}

Trace metal concentrations, grain size distribution, and organic carbon content of ICSV sediment samples are shown in Table II. In general, sediments of the ICSV were classified as sandy or silty sandy (Shepard 1954). General averages are $78 \pm 22 \%$ for sands, followed by silt with $13 \pm 16 \%$, and clay with $9 \pm 7 \%$, with no differences in the average proportions of each size class between dry and rainy seasons, as was previously reported for the ICSV (Rosales-Hoz et al. 2007). However, differences were found between seasons in the grain size distribution of various sampling stations. For example, stations $\mathrm{S} 02, \mathrm{~S} 03, \mathrm{~S} 06, \mathrm{~S} 08 \mathrm{~S} 10$, and S14, had a difference of $20-52 \%$ in their sand content, and of $11-32 \%$ in their silt content. Stations S02, and S10 also had differences of $16-22 \%$ in their clay content. The differences could be explained by sediment resuspension processes or local differences in seasonal sedimentation rates (Rosales-Hoz et al. 2008). In general, sediments collected in this study have a higher average proportion of sand-size grains when compared to previous studies from the ICSV (CelisHernández et al. 2013, 2017) and other inner shelf areas influenced by river discharge in the Southern Gulf of Mexico (Table III). However, Rosales-Hoz et al. (2008) found that sand size grains predominated in samples in front of the city of Veracruz near the Isla de Sacrificios reef in which averages were $>87 \%$. In general, the organic carbon content was $\leq 1 \%$ in almost all samples, except for S09 in the dry season $(4.5 \%)$ and S10 in the rainy season $(3.3 \%)$, which are in the area of influence of fluvial discharge of the Jamapa River. Average organic carbon content in the ICSV was $0.7 \pm 0.9 \%$ for the dry season and $0.8 \pm 0.7 \%$ for the rainy season, with no significant differences between seasons ( $t$-test, $p=0.614$ ). The $\mathrm{OC}$ results are similar to those reported for other areas in the southern Gulf of Mexico (Table III). Hence, it could be assumed that the processes associated with the accumulation of organic carbon in ICSV sediments do not vary between seasons.

\section{Trace metal concentrations}

Average total concentrations of $\mathrm{Cu}(4.96 \pm 3.7$ $\mu \mathrm{g} / \mathrm{g})$ and $\mathrm{Pb}(5.67 \pm 3.6 \mu \mathrm{g} / \mathrm{g})$ in sediments of the ICSV were lower than those reported for other inner shelf areas which are subjected to river influence in the southern Gulf of Mexico (Table III). The average total concentrations of $\mathrm{Cu}(10.2 \mu \mathrm{g} / \mathrm{g})$ and $\mathrm{Pb}$ $(5.0 \mu \mathrm{g} / \mathrm{g})$ in the fluvial sediments of the Jamapa River's outlet (Cabral-Tena et al. 2019) were lower than those in parental igneous rocks $(\mathrm{Cu}: 14.1 \mu \mathrm{g} / \mathrm{g}$; $\mathrm{Pb}: 9.5 \mu \mathrm{g} / \mathrm{g}$ ) from the upper basin of the Jamapa River (Schaaf and Carrasco-Núñez 2010). General averages in the bioavailable fraction were $0.21 \pm$ $0.3 \mu \mathrm{g} / \mathrm{g}$ for $\mathrm{Cu}$ and $0.24 \pm 0.3 \mu \mathrm{g} / \mathrm{g}$ for $\mathrm{Pb}$; these were an order of magnitude lower than average total concentrations. The $\mathrm{Pb}$ bioavailable averages (3.4-6.4 $\mu \mathrm{g} / \mathrm{g}$ ) were also lower than those reported by Ponce-Vélez et al. (2006) for shelf areas influenced by the Coatzacoalcos and Grijalva rivers in the southern Gulf of Mexico. The bioavailable (B) to total content $(\mathrm{T})$ ratio was calculated $(\mathrm{B} / \mathrm{T}=([\mathrm{Metal}]$ $\left.\left.\left.\mathrm{B} /[\text { Metal }]_{\mathrm{T}}\right) \times 100\right)\right)$ for all samples; average values were $\mathrm{Cu}_{\mathrm{B} / \mathrm{T}}=4.9 \pm 5.2 \%$ and $\mathrm{Pb}_{\mathrm{B} / \mathrm{T}}=4.4 \pm 4.4 \%$. Although, sea surface currents transport dissolved and particulate materials to the ICSV (Kasper-Zubillaga and Carranza-Edwards 2003, Carriquiry and HortaPuga 2010, Armstrong-Altrin and Natalhy-Pineda 2013) which might contribute trace elements to the bioavailable fraction of sediments, the main source of organic matter and nutrients in the ICSV is the Jamapa River (Horta-Puga et al. 2020). So, it is interesting to notice that the $\mathrm{Cu}_{\mathrm{B} / \mathrm{T}}$ and $\mathrm{Pb} / \mathrm{B}$ average ratios were lower than those from the fluvial sediments of the Jamapa River $\left(\mathrm{Cu}_{\mathrm{B} / \mathrm{T}}=8.6 \%\right.$; $\left.\mathrm{Pb} / \mathrm{T}=12.6 \%\right)$, the main source of continental materials in the ICSV (Carriquiry and Horta Puga 2010, Cabral-Tena et al. 2019). Samples in the fluvial plume (S08-S10) presented high bioavailable concentrations of $\mathrm{Pb}$ (0.44-0.69 $\mu \mathrm{g} / \mathrm{g})$, but for $\mathrm{Cu}$ bioavailable concentrations were low, especially in the rainy season. 


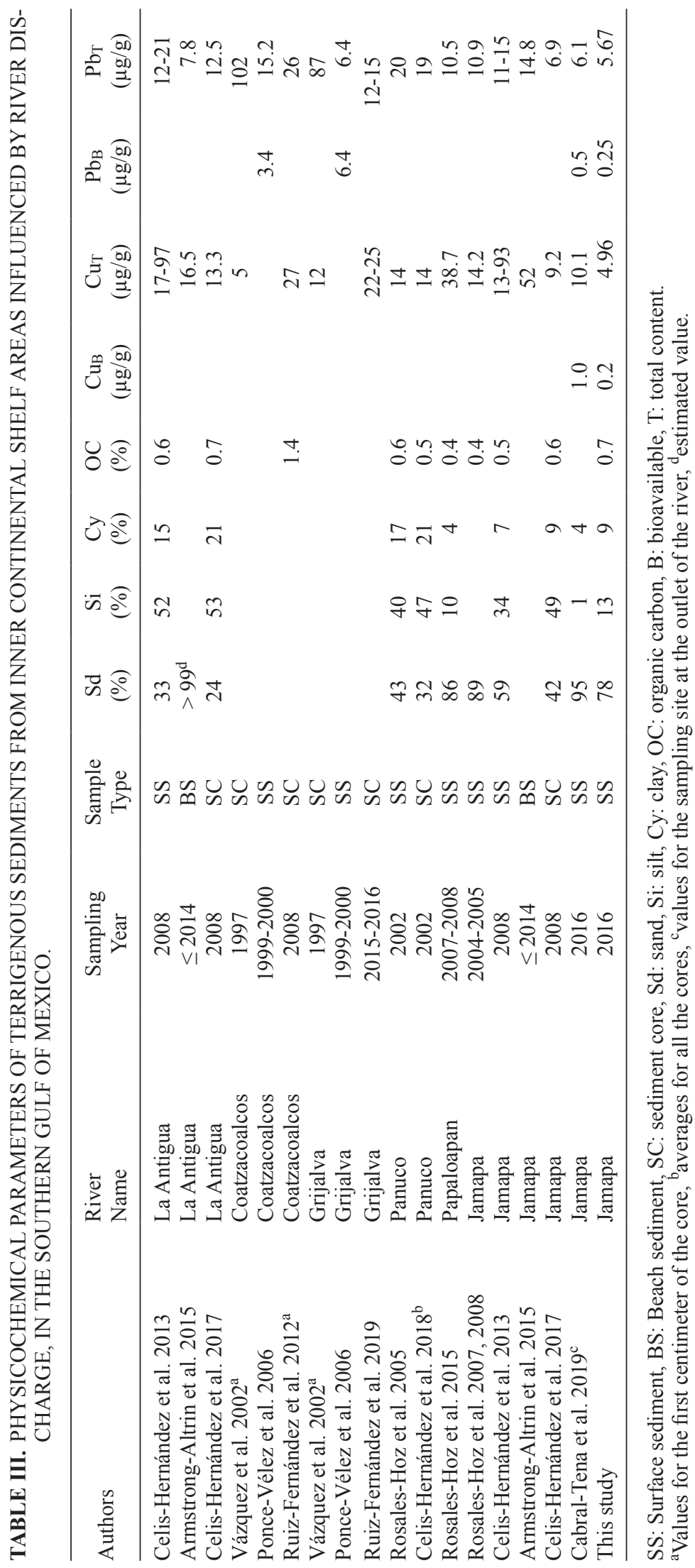


The bioavailable fraction comprises those trace elements associated with the exchangeable, organic and carbonate fractions (Tessier et al. 1979, Tessier and Campbell 1987). These fractions are subject to various environmental processes which contribute to the release or incorporation of trace metals from/ to the dissolved phase in seawater and so change the bioavailable concentration of $\mathrm{Cu}$ and $\mathrm{Pb}$ in sediments. However, with the available information, we are not able to explain why the terrigenous sediments of the ICSV have lower bioavailable concentrations than those from the Jamapa River. Hence, concerning total and especially bioavailable concentrations of $\mathrm{Cu}$ and $\mathrm{Pb}$ in the terrigenous sediments of the ICSV, the area should not be considered as contaminated.

\section{Differences between the dry and rainy seasons}

Total concentrations were higher in the dry season compared to the rainy season (Fig. 2). Averages for the dry season were $5.7 \pm 4.3 \mu \mathrm{g} / \mathrm{g}$ for $\mathrm{Cu}$, and $6.8 \pm$ $4.4 \mu \mathrm{g} / \mathrm{g}$ for $\mathrm{Pb}$; for the rainy season they were 4.2 $\pm 3.0 \mu \mathrm{g} / \mathrm{g}$ for $\mathrm{Cu}$, and $4.5 \pm 1.8 \mu \mathrm{g} / \mathrm{g}$ for $\mathrm{Pb}$. Differences between seasons were significant in both cases (paired t-tests, $\mathrm{p}<0.0230$ ). During the rainy season (June-October) continental runoff increases, causing higher soil erosion rates which concomitantly contribute to increase the load of suspended solids that are transported by the Jamapa River into the ocean (Carriquiry and Horta-Puga 2010, Cabral-Tena et al. 2019). So, finding higher trace metal concentrations during the dry season was unexpected. How might this difference be explained? Carriquiry and HortaPuga (2010) record the concentration of suspended solids in surface seawater in the ICSV, which is, as expected, five times higher during the rainy season $(28.7 \mathrm{mg} / \mathrm{L})$ than during the dry season $(5.6 \mathrm{mg} / \mathrm{L})$. However, recorded sedimentation rates are three times higher in the dry season $\left(0.31 \mathrm{~kg} / \mathrm{m}^{2} /\right.$ day $)$ than in the rainy season $\left(0.09 \mathrm{~kg} / \mathrm{m}^{2} /\right.$ day $)$ (Horta-Puga 2017). So, although the load of suspended sediments is lower in the dry season, sedimentation rates are higher. A plausible explanation for this observed pattern is as follows. Salas-Monreal et al. (2019) observed in the ICSV, that in the northern cold fronts season, from October to March or April, which include the dry season in part (Carrillo et al. 2007), strong northerly winds (wind stress $>0.07 \mathrm{~N} / \mathrm{m}^{2}$ ) mix the entire water column and suspended sediments might easily reach the bottom as the water column is not stratified, enhancing higher sedimentation rates and, concomitantly, higher concentrations of trace elements. However, RosalesHoz et al. (2007) suggested that the same strong winds (that occur during the cold front season) tend to mix
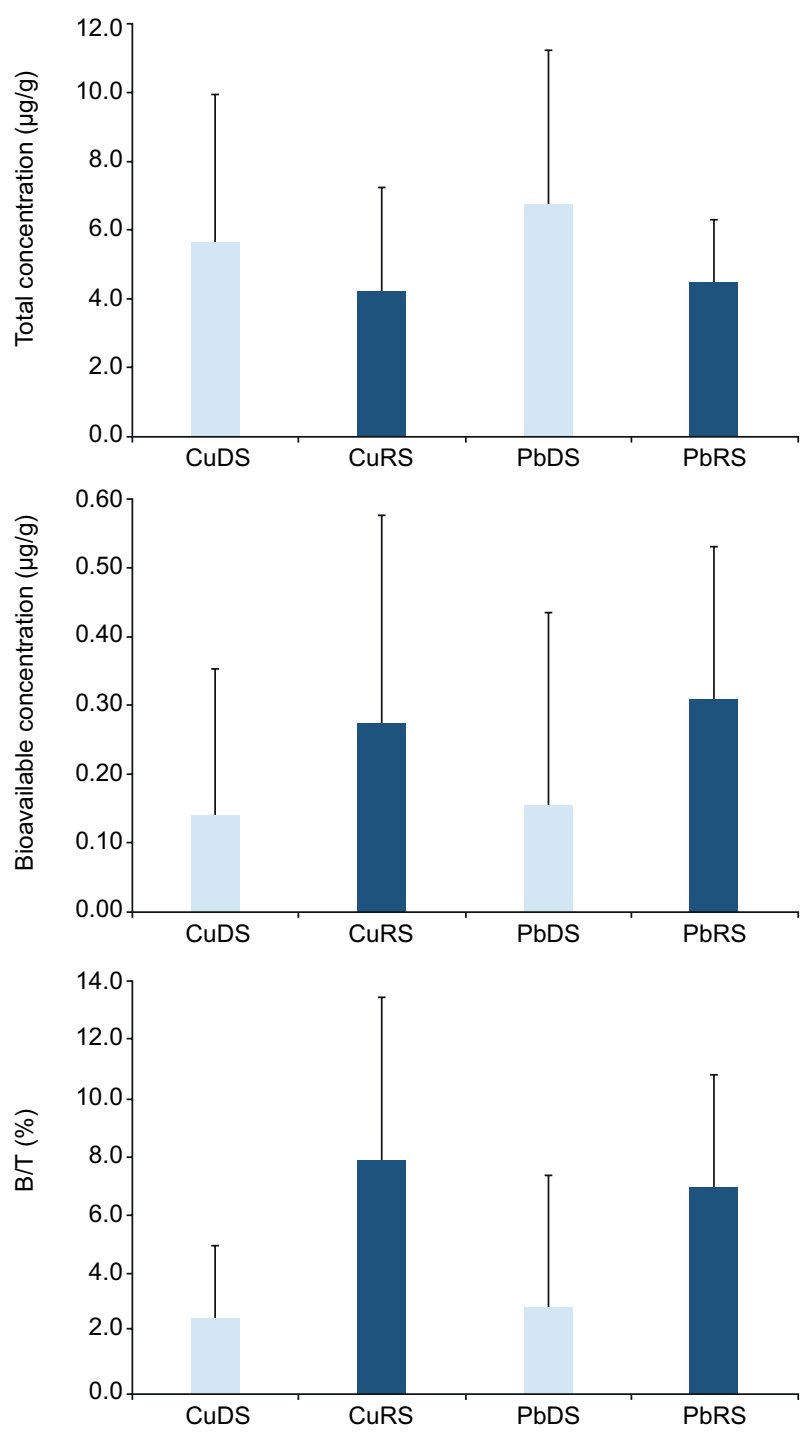

Fig. 2. Average bioavailable and total $\mathrm{Cu}$ and $\mathrm{Pb}$ concentrations $(\mu \mathrm{g} / \mathrm{g})$, and the $\mathrm{B} / \mathrm{T}$ ratio between the bioavailable/total trace metal concentrations (\%), in the dry (DS) and rainy (RS) seasons, in terrigenous sediments of the ICSV. Standard deviation $(1 \sigma)$ is shown as a line over the bar.

the bottom sediments, causing lower concentrations of $\mathrm{Cu}$ and $\mathrm{Pb}$. This issue should be more thoroughly evaluated in future studies.

For the bioavailable fraction, concentrations were higher in the rainy season (Fig. 2), as expected given that it is the season with the higher riverine influence. Differences were significant between seasons in all cases (paired t-tests, $\mathrm{p}<0.0246$ ), with the exception of bioavailable $\mathrm{Pb}$ average concentrations (paired $\mathrm{t}$-test, $\mathrm{p}=0.053$ ). Also, in the rainy season, the proportion of $\mathrm{Cu}$ and $\mathrm{Pb}$ associated to the bioavailable fraction increased $\left(\mathrm{Cu}_{\mathrm{B} / \mathrm{T}-\mathrm{RS}}=7.8 \pm 5.8 \%>\mathrm{Cu}_{\mathrm{B} / \mathrm{T}-\mathrm{DS}}\right.$ $=2.2 \pm 2.6 \% ; \mathrm{Pb}_{\mathrm{B} / \mathrm{T}-\mathrm{RS}}=7.0 \pm 3.8 \%>\mathrm{Pb}_{\mathrm{B} / \mathrm{T}-\mathrm{DS}}=2.0$ 
$\pm 3.6 \%$ ), and differences were statistically significant (paired t-tests, $\mathrm{p}<0.0002$ ).

\section{DISCUSSION}

\section{The city of Veracruz as a source of trace metals}

Veracruz is the most important city and cargo port in the southern Gulf of Mexico. It has a population of over 810000 (https://www.inegi.org.mx). At its port, 1998 large cargo ships docked in 2016 which loaded/ discharged a total of $24.5 \times 10^{6}$ tons of goods (https:// www.puertodeveracruz.com.mx). Consequently, human activities that take place in the city and port are an important source of contaminants including trace metals (Rosales-Hoz et al. 2007, Horta-Puga et al. 2013). Thus, to determine the potential environmental impact of the city and port of Veracruz, average concentrations of trace metals were compared between sampling NS and OS stations situated (Fig. 3). The

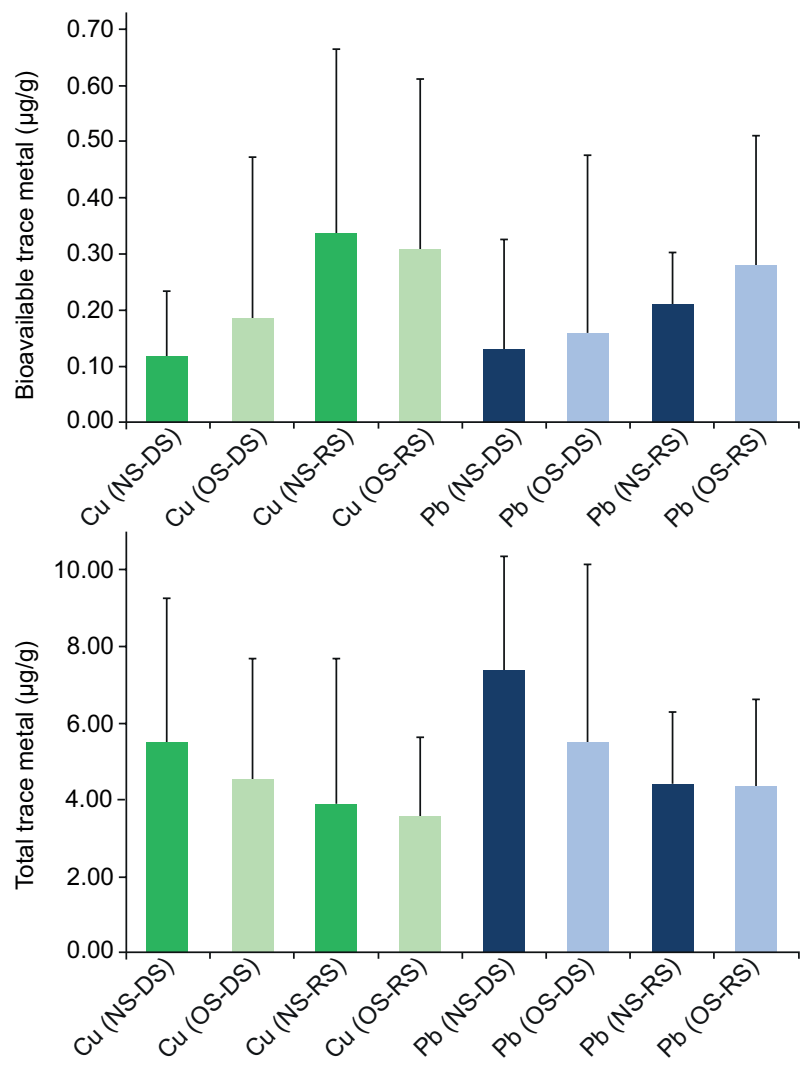

Fig. 3. $\mathrm{Cu}$ (green bars) and $\mathrm{Pb}$ (blue bars) total and bioavailable average concentrations $(\mu \mathrm{g} / \mathrm{g} \pm \sigma)$ in the terrigenous sediments of the inner continental shelf of Veracruz, in the dry (DS) and rainy (RS) seasons, for the nearshore (NS) and offshore (OS) sampling stations. Standard deviation $(1 \sigma)$ is shown as a line over the bar.
NS group comprises the stations S07, S11, S12, S13, S15, S20, S21, S22, but excluding S08, S09 and S10 because they received the direct influence of the Jamapa River; the remaining stations composed the OS group. Total average concentrations for $\mathrm{Cu}$ and $\mathrm{Pb}$ were always higher in the NS group, both in dry and rainy seasons. Bioavailable concentrations in general were higher in the OS group, with the exception of $\mathrm{Cu}$ in the rainy season. However, in all cases no statistically significant differences were found between the average bioavailable or total concentrations of the NS and OS groups (Mann-Whitney test, $p>0.2854)$. Hence, human activities that take place in the city (i.e., non-point sources of contamination) apparently do not contribute significantly to increases in levels of these trace elements.

As stated above, trace element total concentrations were higher NS than OS, but were even higher in the NS sampling stations (S20, S21, and S22) located to the north of the city (Fig. 4). Construction of the New Port of Veracruz, located immediately to the north of the old port facilities, began in 2014. The project included the construction of a $4.2 \mathrm{~km}$ breakwater, and several terminals (fluid, multipurpose, container, agricultural bulk and mineral bulk) which can receive larger cargo ships to increase the handling of goods in Veracruz (SCT 2016). The breakwater built by the dumping of stones and concrete armor units and

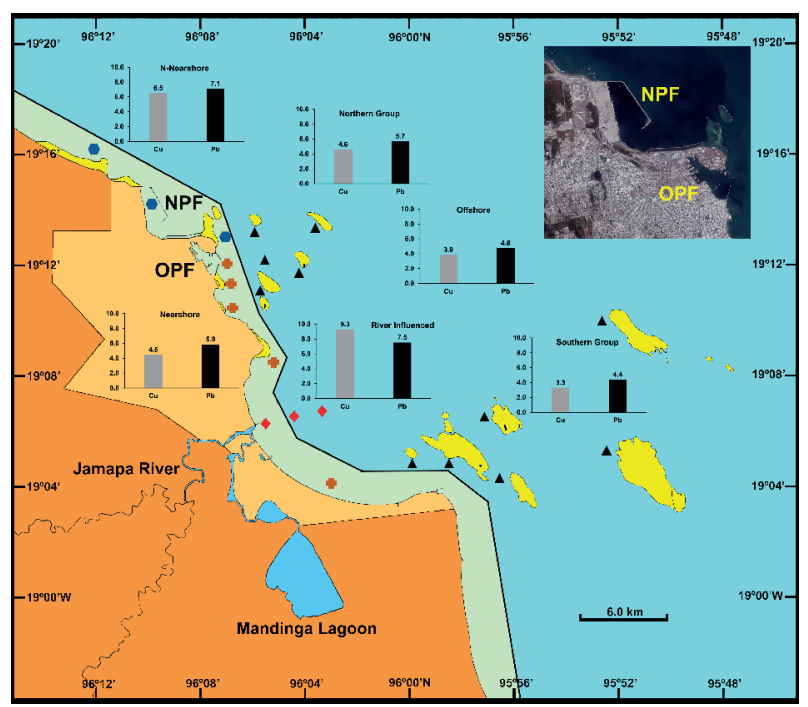

Fig. 4. $\mathrm{Cu}$ and $\mathrm{Pb}$ total concentrations $(\mu \mathrm{g} / \mathrm{g} \pm \sigma)$ in the terrigenous sediments of the inner continental shelf of Veracruz, in the dry and rainy seasons, for the northern group (GN: blue bars), southern group (GS: green bars), and the outlet of the Jamapa River (OJ: brown bars). Standard deviation $(1 \sigma)$ is shown as a line over the bar. 
the dredging of the port harbor produced sediments and the resuspension of previously deposited sediments, which probably contributed to increases in concentrations of $\mathrm{Cu}$ and $\mathrm{Pb}$ in the vicinity of the new port facilities zone.

\section{The Jamapa River as source of trace metals}

To determine the influence of the Jamapa River, sampling stations were sorted into three groups: those to the south of the Jamapa mouth (GS: S01-S07), those to the north (GN: S11-S22), and those directly situated at the path of the fluvial plume, near the outlet of the Jamapa River (OJ: S08-S10). As can be seen in Fig. 5, average total concentrations of $\mathrm{Cu}$ and $\mathrm{Pb}$ were higher in the OJ stations, both in the dry season $(\mathrm{Cu}: 11.1 \pm 11.1 \mu \mathrm{g} / \mathrm{g}, \mathrm{Pb}: 10.4 \pm 6.33 \mu \mathrm{g} / \mathrm{g})$ and in the rainy season $(\mathrm{Cu}: 7.54 \pm 3.22 \mu \mathrm{g} / \mathrm{g}, \mathrm{Pb}$ : $4.66 \pm 0.42 \mu \mathrm{g} / \mathrm{g}$ ), when compared to the GN and GS groups. So, as expected, the Jamapa River is an
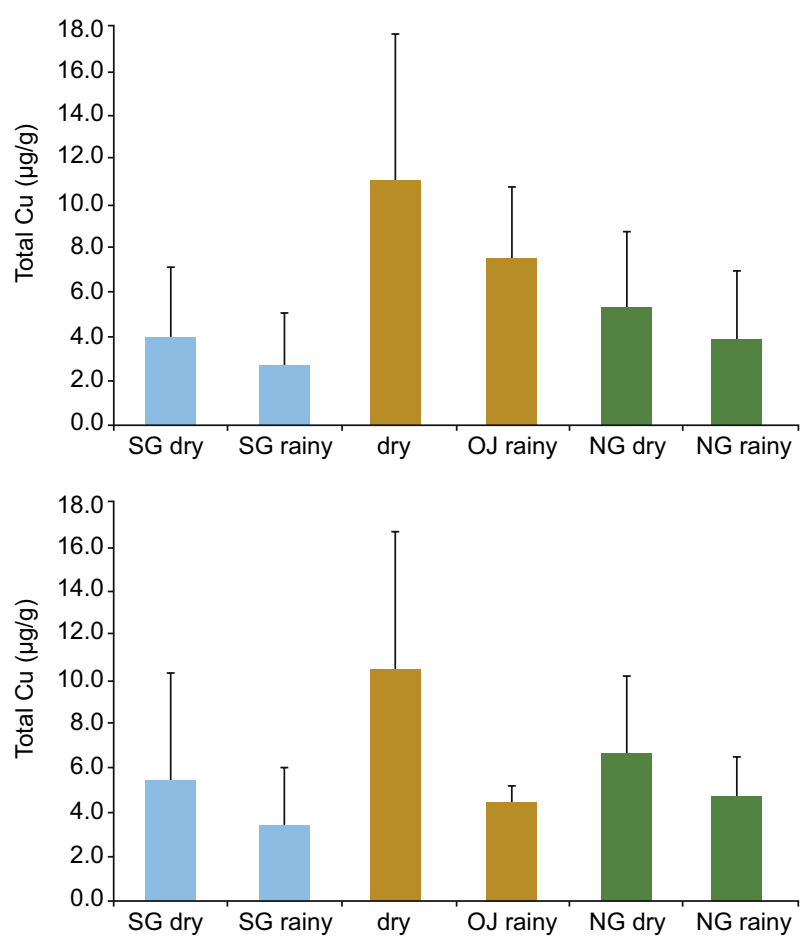

Fig. 5. Average total $\mathrm{Cu}$ and $\mathrm{Pb}$ concentrations $(\mu \mathrm{g} / \mathrm{g})$ in the inner continental shelf adjacent to Veracruz in the southern Gulf of Mexico. Nearshore area: light green; offshore area: light blue; emergent coral reefs: yellow areas; offshore sampling stations: black triangles; nearshore sampling stations: brown crosses; nearshore sampling stations, north of the city of Veracruz: blue hexagons; Jamapa River fluvial plume sampling stations: red diamonds. OPF: old port facilities; NPF: new port facilities. Right corner insert: Port of Veracruz, from Google Earths. important source of $\mathrm{Cu}$ and $\mathrm{Pb}$, which are included, mainly, in the siliciclastic fraction that constitutes the bulk of sediments in the ICSV, as previously suggested for $\mathrm{Cu}$ and/or $\mathrm{Pb}$ (Rosales-Hoz et al. 2007, Horta-Puga and Carriquiry 2014, Celis-Hernández et al. 2017, Horta-Puga 2017), Ba (Carriquiry and Horta-Puga 2010), and very probably for other trace metals. Another interesting result is that sediments in the GN, both in dry and rainy seasons, exhibited slightly higher average total concentrations of both elements than those from the GS (Fig. 4), although differences were not significant in any case (MannWhitney test, $p>0.2614)$. A plausible explanation for this is that during the rainy season, northward surface currents in the ICSV, with speeds of 24-30 m/s (Chacón-Gómez et al. 2013; Avendaño-Álvarez et al. 2017), might transport suspended sediments of the Jamapa's fluvial plume to the north, at the very moment when the sediment load is higher (Carriquiry and Horta-Puga 2010). However, this hypothesis needs adequate study to be properly evaluated.

\section{Trace elements temporal trends}

It is important to notice that total concentrations of $\mathrm{Cu}$ and $\mathrm{Pb}$ recorded here are lower than all other records from terrigenous sediments on continental shelf areas influenced by fluvial discharges in the southern Gulf of Mexico. Except for the results of Cabral-Tena et al. (2019), and Ruiz-Fernández et al. (2019), who collected samples in 2016, all other studies were performed in 2008 or before (Table III). So, it is possible that trace element concentrations could be decreasing in the ICSV, at least during the last decade. Figure 6 shows the temporal variability of $\mathrm{Cu}$ and $\mathrm{Pb}$ concentrations in the ICSV for the period from 2005 to 2016. Although both series exhibit a decreasing trend through time, none were statistically significant (Pearson correlation, $\mathrm{Cu}: \mathrm{r}=-0.399, \mathrm{p}=0.505 ; \mathrm{Pb}$ : $\mathrm{r}=-0.743, \mathrm{p}=0.149$ ). In the case of $\mathrm{Cu}$, known sources are terrigenous sediments from the Jamapa River (Rosales-Hoz et al. 2007) and antifouling paints used on the hulls of ships and boats (Horta-Puga et al. 2013). As these two processes are still occurring, we have no explanation for the lower concentrations of $\mathrm{Cu}$ in recent times. On the other hand, Horta-Puga and Carriquiry (2014) found that concentrations of $\mathrm{Pb}$ in the annual growth bands of the scleractinian coral Orbicella faveolata peaked in 1992, the year with the highest annual consumption rate of leaded gasoline in Mexico, and then concentrations began to decrease. Nowadays, the most important source of $\mathrm{Pb}$ in the ICSV are previously deposited $\mathrm{Pb}$ aerosols, which are transported from eroded continental soils 


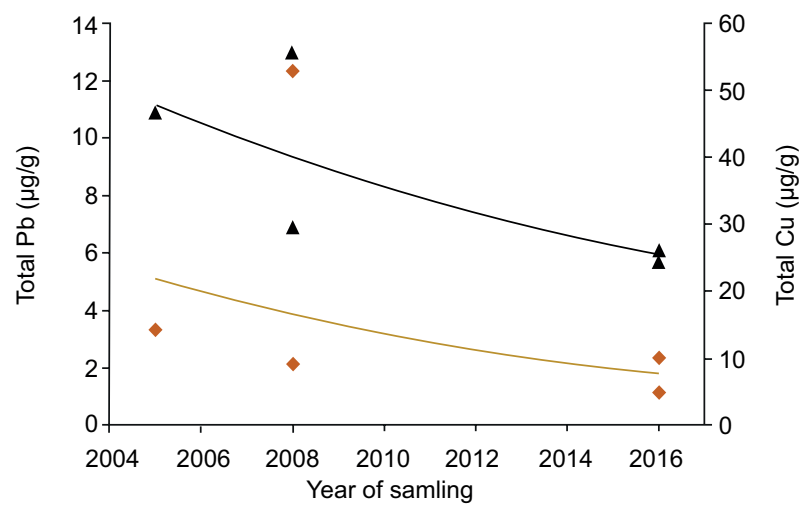

Fig. 6. Temporal variability in the total concentration of $\mathrm{Cu}$ and $\mathrm{Pb}$, in terrigenous sediments from the ICSV. Lines are the best fit from the regression analyses. $\mathrm{Cu}$ : brown line and diamonds; $\mathrm{Pb}$ : black line and triangles.

to the ocean by river waters (Horta-Puga et al. 2013, Horta-Puga and Carriquiry 2014, Horta-Puga 2017). As this source is continuously decreasing (due to the depletion of $\mathrm{Pb}$ aerosols from soils through time), it is possible that environmental concentrations of $\mathrm{Pb}$ in the ICSV will continue their decreasing trend in the future.

\section{Association of trace metals with sediment para- meters}

The concentrations of trace metals in sediments from freshwater, estuarine and/or marine depositional environments are generally highly associated with the content of terrigenous siliciclastic particles, mainly fine particles like clay and silt from continental origin (Rosales-Hoz et al. 2007, Celis-Hernández et al. 2013, 2017, Horta-Puga 2017, Cabral-Tena et al. 2019). So, as expected, in the terrigenous sediments of the ICSV, high and significant correlations
(Pearson: $r>0.5, p<0.05$ ) were found among total $\mathrm{Cu}$ and $\mathrm{Pb}$, both in the dry and rainy season, and sediment grain size (clay, silt, and/or mud), for almost all cases (Table IV), was also found by Celis-Hernández et al. (2013). This is additional evidence of the continental origin of trace metals in the ICSV. Also, as expected, low and non-significant correlations were found with $\mathrm{Cu}$ and $\mathrm{Pb}$ in the bioavailable fraction. An unexpected result was the high correlation between organic carbon and total $\mathrm{Cu}$ and $\mathrm{Pb}$ concentrations. Organic carbon accounts, on average, for just $0.7 \%$ in samples, and trace metals contained in the bioavailable fraction, the one that includes organic matter in sediments, accounts for just 4.4-4.9\% of the total concentration. The organic carbon content of sediments is dependent on various environmental processes, both intrinsic (primary production and consumption rates), and extrinsic (particulate organic external inputs), as has been reported for the ICSV (Rosales-Hoz et al. 2008). So, the potential cause of the correlation is unknown.

\section{Environmental quality of the ICSV}

The range and average concentrations recorded here for $\mathrm{Cu}$ and $\mathrm{Pb}$ in terrigenous surface sediments of the ICSV (both total and bioavailable) are lower than: (1) records for marine terrigenous sediments from the southern Gulf of Mexico (Table III); (2) the maximum permissible limits of $\mathrm{Cu}$ and $\mathrm{PB}(31$ and $35 \mu \mathrm{g} / \mathrm{g}$, respectively), established by national environmental regulations (Canada: CCME 1995; Australia and New Zealand: ANZEEC 2013; USA: EPA 1997; Mexico: SEMARNAT 2002); (3) background concentrations $(\mathrm{Cu}=25 \mu \mathrm{g} / \mathrm{g} ; \mathrm{Pb}=20 \mu \mathrm{g} / \mathrm{g})$ in the upper continental crust (Taylor and Mclennan 1995) and igneous rocks $(\mathrm{Cu}=10 \mu \mathrm{g} / \mathrm{g} ; \mathrm{Pb}=$ $19 \mu \mathrm{g} / \mathrm{g}$ ) (Turekian and Wedepohl 1961); and (4)

TABLE IV. PEARSON'S SIMPLE LINEAR CORRELATION ANALYSES AMONG Cu AND Pb CONCENTRATIONS (BIOAVAILABLE AND TOTAL CONTENT), AND SEDIMENT PHYSICOCHEMICAL PARAMETERS.

\begin{tabular}{cccccc}
\hline $\mathrm{S}$ & $\mathrm{HM}$ & Silt & Clay & Mud & OM \\
\hline & $\mathrm{Cu}_{\mathrm{B}}$ & $\mathrm{r}=0.335, \mathrm{p}=0.127$ & $\mathrm{r}=0.367, \mathrm{p}=0.092$ & $\mathrm{r}=0.336, \mathrm{p}=0.093$ & $\mathrm{r}=0.100, \mathrm{p}=0.656$ \\
$\mathrm{DS}$ & $\mathrm{Cu}_{\mathrm{T}}$ & $\mathrm{r}=0.856, \mathrm{p}<0.001$ & $\mathrm{r}=0.722, \mathrm{p}<0.001$ & $\mathrm{r}=0.852, \mathrm{p}<0.001$ & $\mathrm{r}=0.853, \mathrm{p}<0.001$ \\
& $\mathrm{~Pb}_{\mathrm{B}}$ & $\mathrm{r}=0.157, \mathrm{p}=0.482$ & $\mathrm{r}=-0.083, \mathrm{p}=0.710$ & $\mathrm{r}=0.072, \mathrm{p}=0.748$ & $\mathrm{r}=-0.065, \mathrm{p}=0.772$ \\
& $\mathrm{~Pb}_{\mathrm{T}}$ & $\mathrm{r}=0.577, \mathrm{p}=0.004$ & $\mathrm{r}=0.394, \mathrm{p}=0.069$ & $\mathrm{r}=0.538, \mathrm{p}=0.009$ & $\mathrm{r}=0.566, \mathrm{p}=0.005$ \\
\hline & $\mathrm{Cu}_{\mathrm{B}}$ & $\mathrm{r}=-0.102, \mathrm{p}=0.659$ & $\mathrm{r}=-0.117, \mathrm{p}=0.611$ & $\mathrm{r}=-0.112, \mathrm{p}=0.627$ & $\mathrm{r}=-0.062, \mathrm{p}=0.788$ \\
& $\mathrm{Cu}$ & $\mathrm{r}=0.571, \mathrm{p}=0.006$ & $\mathrm{r}=0.555, \mathrm{p}=0.008$ & $\mathrm{r}=0.598, \mathrm{p}=0.004$ & $\mathrm{r}=0.675, \mathrm{p}<0.001$ \\
$\mathrm{RS}$ & $\mathrm{Pb}_{\mathrm{B}}$ & $\mathrm{r}=0.450, \mathrm{p}=0.040$ & $\mathrm{r}=0.327, \mathrm{p}=0.147$ & $\mathrm{r}=0.440, \mathrm{p}=0.045$ & $\mathrm{r}=0.317, \mathrm{p}=0.160$ \\
& $\mathrm{~Pb}_{\mathrm{T}}$ & $\mathrm{r}=0.300, \mathrm{p}=0.185$ & $\mathrm{r}=0.383, \mathrm{p}=0.085$ & $\mathrm{r}=0.341, \mathrm{p}=0.129$ & $\mathrm{r}=0.277, \mathrm{p}=0.223$ \\
\hline
\end{tabular}

S: season, HM: heavy metal, Mud: silt + clay, OM: organic matter, DS: dry season, RS: rainy season, B: bioavailable, T: total content. 
concentrations reported for the igneous parental rocks in the upper basin of the Jamapa River $(\mathrm{Cu}$ $=14.1 \mu \mathrm{g} / \mathrm{g} ; \mathrm{Pb}=9.5 \mu \mathrm{g} / \mathrm{g}$ ) (Schaaf and CarrascoNúñez 2010). Hence, it is clear that the ICSV should not be considered to be polluted by these elements like the Jamapa River (Cabral-Tena et al. 2019), an important source of trace metals to the ICSV. In addition, considering that the bioavailable trace metals concentrations are one order of magnitude lower than the total concentrations, the organisms that live in the ICSV are at least not threatened by $\mathrm{Cu}$ and $\mathrm{Pb}$.

\section{CONCLUSIONS}

The Jamapa River is a large fluvial system which drains its waters from a watershed of $\sim 4061 \mathrm{~km}^{2}$ directly in the coastal area of the City of Veracruz in the southern Gulf of Mexico. As the river receives urban and industrial pluvial and sewage waters and runoff from agricultural lands, it is considered a potential source of trace metals and other pollutants to the adjacent ICSV. Also, the city and its industrial port potentially contribute pollutants. Hence, high concentrations of trace metals, like $\mathrm{Cu}$ and $\mathrm{Pb}$ were expected, both in the bioavailable fraction and the total content of the ICSV's surface sediments. Based on the results of this study, which is the first to evaluate $\mathrm{Cu}$ and $\mathrm{Pb}$ in the bioavailable fraction of terrigenous sediments in the ICSV, it can be concluded that: (1) these sediments are predominantly sandy, with a low content of organic carbon $(\leq 1 \%)$; (2) total and bioavailable trace metals concentrations are lower compared with values from other inner shelf areas in the southern Gulf of Mexico; (3) the bioavailable fraction accounts for only $4.4-4.9 \%$ of the total content, which is lower than the average for the same trace metals in the fluvial sediments of the Jamapa River; (4) total concentrations were higher in the dry season, which could be explained by high sedimentation rates, caused by stronger winds; (5) as expected, bioavailable trace metals exhibited higher concentrations during the rainy season; (6) nearshore trace metals concentrations are not higher than at offshore sites (i.e., far from the city influence); (7) nearshore sampling stations located adjacent to the New Port of Veracruz area exhibited high trace element concentrations; (8) sampling stations located in the path of the fluvial plume of the Jamapa River exhibited the highest concentrations, supporting the assumption that the river is a main source of trace metals into the ICSV; (9) due to the depletion of $\mathrm{Pb}$ aerosols previously deposited on continental soils through time, it is probable that $\mathrm{Pb}$ environmental concentrations in the ICSV will also continue decreasing in the future; (10) as expected, high and significant correlations were found between total $\mathrm{Cu}$ and $\mathrm{Pb}$, and fine sediments, which also could be evidence of the continental origin of trace metals in the ICSV; and (11) the total and bioavailable concentrations of $\mathrm{Cu}$ and $\mathrm{Pb}$ are lower when compared to other shelf areas in the southern Gulf of Mexico, background levels, and maximum permissible limits, so the ICSV should not be considered to be contaminated by $\mathrm{Cu}$ or $\mathrm{Pb}$.

\section{ACKNOWLEDGMENTS}

We would like to thank Joseph Loustalot Laclette (SCUBAVER) for his support in the field work. Thanks to Alexis Trejo, Alfonso Martínez, Carlos Lozano, and Estefanía Navarro (FES Iztacala, UNAM), for their help in the collection and processing of sediment samples. This study was financed by a grant (PAPIIT IN114616) to G. Horta-Puga, and a postdoctoral fellowship to R.A. Cabral-Tena, both from DGAPA, UNAM, Mexico. Many thanks to Dr. Thomas F. Duda (University of Michigan), who kindly accepted to make the English language edition of this MS. The comments and suggestions of an anonymous reviewer contributed to notably improve this study.

\section{REFERENCES}

ANZECC (1997). ANZECC interim sediment quality guidelines. Report for the Environmental Research Institute of the Supervising Scientist. Australian and New Zealand Environment and Conservation Council, Sydney, Australia.

Armstrong-Altrin J.S. and Natalhy-Pineda O. (2013). Microtextures of detrital sand grains from the Tecolutla, Nautla, and Veracruz beaches, western Gulf of Mexico, Mexico: implications for depositional environment and paleoclimate. J. Arab. Geosci. 7, 4321-4333. https:// doi.org/10.1007/s12517-013-1088-x

Armstrong-Altrin J.S., Nagajaran R., Balaram V., and Natalhy-Pineda O. (2015). Petrography and geochemistry of sands from the Chachalacas and Veracruz beach areas, western Gulf of Mexico, Mexico: Constraints on provenance and tectonic setting. J. South Amer. Earth Sci. 64, 199-216. https://doi.org/10.1016/j. jsames.2015.10.012 
Avendaño-Álvarez O., Salas-Monreal D., Marín-Hernández M., Salas-de-León D.A., and Monreal-Gómez, M.A. (2017). Annual hydrological variation and hypoxic zone in a tropical coral reef system. Reg. Stud. Mar. Sci. 9, 145-155. https://doi.org/10.1016/j. rsma.2016.12.007

Cabral-Tena R.A., Córdova A., López-Galindo F., Morales-Aranda A.A., Reyes-Mata A., Soler-Aburto A. and Horta-Puga G. (2019). Distribution of the bioavailable and total content of copper and lead, in river sediments of the Jamapa-Atoyac fluvial system, Mexico. Environ. Monit. Assess. 191, 214. https://doi. org/10.1007/s10661-019-7353-z

Carricart-Ganivet J.P. and Horta-Puga G. (1993). Arrecifes de coral en México. In: Biodiversidad marina y costera de México (Salazar-Vallejo S.I. and González N.E., Eds.). Comisión Nacional para el Conocimiento y Aprovechamiento de la Biodiversidad (CONABIO)Centro de Investigaciones de Quintana Roo (CIQRO), Chetumal, Quintana Roo, Mexico, 80-90.

Carrillo L., Horta-Puga G. and Carricart-Ganivet J.P. (2007). Climate and oceanography. In: Coral reefs of the Southern Gulf of Mexico (Tunnell J.W., Chávez E.A. and Whithers K., Eds.). Texas A\&M University Press, College Station, Texas, USA, 34-40.

Carriquiry J.D. and Horta-Puga G. (2010). The $\mathrm{Ba} / \mathrm{Ca}$ record of corals from the Southern Gulf of Mexico: Contributions from land-use changes, fluvial discharge, and oil-drilling muds. Mar. Pollut. Bull. 60, 1625-1630. https://doi.org/10.1016/j.marpolbul.2010.06.007

CCME (1995). Protocol for the derivation of Canadian sediment quality guidelines for the protection of aquatic life. Report CCME EPC-98E. Canadian Council of Ministers of the Environment, Ottawa, Canada, 47 pp.

Celis-Hernández O., Rosales-Hoz L. and CarranzaEdwards A. (2013). Heavy metal enrichment in surficial sediments from the SW Gulf of Mexico. Environ. Monit. Assess. 185, 8891-8907. https://doi. org/10.1007/s10661-013-3222-3

Celis-Hernández O., Rosales-Hoz L., Cundy A.B. and Carranza-Edwards A. (2017). Sedimentary heavy metal(loid) contamination in the Veracruz shelf, Gulf of Mexico: A baseline survey from a rapidly developing tropical coast. Mar. Pollut. Bull. 119, 204-213. https:// doi.org/10.1016/j.marpolbul.2017.03.039

Celis-Hernández O., Rosales-Hoz L., Cundy A.B., Carranza-Edwards A., Croudace I.W. and Hernández-Hernández H. (2018). Historical trace element accumulation in marine sediments from the Tamaulipas shelf, Gulf of Mexico: An assessment of natural vs anthropogenic inputs. Sci. Tot. Environ. 622-623, 325-336. https:// doi.org/10.1016/j.scitotenv.2017.11.228
Chacón-Gómez I.S., Salas-Monreal D. and RiverónEnzástiga M.L. (2013). Current pattern and coral larval dispersion in a tropical coral reef system. Cont. Shelf Res. 68, 23-32. https://doi.org/10.1016/j. csr.2013.08.014

Dassenakis M., Scoullos M. and Gaitis A. (1997). Trace metals transport and behaviour in the Mediterranean estuary of Acheloos river. Mar. Pollut. Bull. 34, 103-111. https://doi.org/10.1016/S0025326X(96)00062-8

De Vos B., Lettens S., Muys B. and Deckers J.A. (2007). Walkley-Black analysis of forest soil organic carbon: Recovery, limitations and uncertainty. Soil Use Manage. 23, 221-229. https://doi.org/10.1111/j.14752743.2007.00084.x

Dupré B., Gallairdet J., Roussseau D. and Allègre C.J. (1996). Major and trace elements of river-borne material: The Congo Basin. Geochim. Cosmochim. Acta. 60, 1301-1321. https://doi.org/10.1016/00167037(96)00043-9

Emery K.O. (1963). Regional studies, coral reefs off Veracruz, Mexico. Geofísica Internacional 3, 11-17.

EPA (1997). The incidence and severity of sediment contamination in surface waters of the United States. Vol. 1: National sediment quality survey. EPA 823-R-97006. United States Environmental Protection Agency, Washington, D.C., USA, 302 pp.

Gutiérrez-de Velasco G. and Winant C.D. (1996). Seasonal patterns of wind stress and wind stress curl over the Gulf of Mexico. J. Geophys. Res. 101, 127-140. https:// doi.org/10.1029/96JC01442

Hammer Ø., Harper D.A.T. and Ryan P.D. (2001). PAST: Paleontological statistics software package for education and data analysis. Palaeontologia Electronica 4 (1), 9. http://palaeo-electronica.org/2001_1/past/ issue1_01.htm

Horta-Puga G. (2007). Environmental impacts. In: Coral reefs of the Southern Gulf of Mexico (Tunnell J.W., Chávez E.A. and Whithers K., Eds.). Texas A\&M University Press, College Station, Texas, USA, 126-142.

Horta-Puga G., Cházaro-Olvera S., Winfield I., ÁvilaRomero M. and Moreno-Ramírez M. (2013). Cadmium, copper and lead in macroalgae from the Veracruz Reef System, Gulf of Mexico: Spatial distribution and rainy season variability. Mar. Pollut. Bull. 68, 127-133. https://doi.org/10.1016/j.marpolbul.2012.12.008

Horta-Puga G. and Carriquiry J.D. (2014). The last two centuries of lead pollution in the southern Gulf of Mexico recorded in the annual bands of the scleractinian coral Orbicella faveolata. Bull. Environ. Contam. Toxicol. 92, 567-573. https://doi.org/10.1007/s00128014-1222-9 
Horta-Puga G., Tello-Musi J.L., Beltrán-Torres A., Carricart-Ganivet J.P., Carriquiry J.D. and VillaescusaCelaya J. (2015). Veracruz Reef System: A hermatypic coral community thriving in a sedimentary terrigenous environment. In: Aportes al conocimiento del Sistema Arrecifal Veracruzano: hacia el Corredor Arrecifal del Suroeste del Golfo de México (Granados-Barba A., Ortiz-Lozano L., Salas-Monreal D. and GonzálezGándara C., Eds.). Universidad Autónoma de Campeche, Campeche, Mexico, 181-208.

Horta-Puga G. (2017). Geochemical partitioning of lead in biogenic carbonate sediments in a coral reef depositional environment. Mar. Pollut. Bull. 116, 71-79. https://doi.org/10.1016/j.marpolbul.2016.12.049

Horta-Puga G., Tello-Musi J.L., Córdova A., GutiérrezCarrillo A., Gutiérrez-Martínez J., Morales-Aranda A.A. (2020). Spatio-temporal variability of benthic macroalgae in a coral reef system highly influenced by fluvial discharge: Veracruz, Gulf of Mexico. Mar. Ecol. 41 (4), 00:e12596. https://doi.org/10.1111/ maec. 12596

Kasper-Zubillaga J.J., Carranza-Edwards A., Rosales-Hoz L. (1999). Petrography and geochemistry of Holocene sands in the western Gulf of Mexico: Implications for provenance and tectonic setting. J. Sedim. Res. 69, 1003-1010. https://doi.org/10.2110/jsr.69.1003

Kasper-Zubillaga J.J., Carranza-Edwards A. (2003). Modern sands of the Gulf of Mexico: Discriminating fluvial and coastal sand composition. Ciencias Marinas 29, 621-630. https://doi.org/10.7773/cm.v29i42.195

Kaushik A., Kansal A., Meena S., Kumari S. and Kaushik C.P. (2009). Heavy metal contamination of river Yamuna, Haryana, India: Assessment by metal enrichment factor of sediments. J. Hazard. Mater. 164, 265-270. https://doi.org/10.1016/j.jhazmat.2008.08.031

Luoma S. (1989). Can we determine the biological availability of sediment-bound trace elements? Hydrobiologia 176/177, 379-396. https://doi.org/10.1007/ BF00026572

Martin J.M. and Whitfield M. (1983). The significance of river input of chemical elements to the ocean. In: Trace metals in sea water (Wong C.S., Boyle E., Bruland K.W., Burton J.D. and Goldberg E.D., Eds.). NATO Conference Series (IV Marine Sciences), vol 9. Springer, Boston, Massachusetts, USA, 265-296.

Milliman J.D. and Meade R.H. (1983). World-wide delivery of river sediments to the oceans. J. Geol. 91, 1-21. https://www.jstor.org/stable/30060512

Milliman J.D., Rutkowski C. and Meybeck M. (1995). River discharge to the sea: A global river index (GLORI). LOICZ Reports and Studies, Netherlands Institute for Sea Research, The Hague, Netherlands, $125 \mathrm{pp}$.
Morelock J. and Koenig K.J. (1967). Terrigenous sedimentation in a shallow water coral reef environment. J. Sedim. Petrol.37, 1001-1005. https://doi.org/10.1306/74D718112B21-11D7-8648000102C1865D

Ortiz-Lozano L. (2012). Identification of priority conservation actions in marine protected areas: Using causal networks approach. Ocean Coast. Manage. 55, 74-83. https://doi.org/10.1016/j.ocecoaman.2011.10.013

Ponce-Vélez G., Botello A.V. and Díaz-González G. (2006). Organic and inorganic pollutants in marine sediments from the northern and southern continental shelf of the Gulf of Mexico. Int. J. Environment Pollut. 26, 295-311. https://doi.org/10.1504/IJEP.2006.009113

Rosales-Hoz L., Carranza-Edwards A., Santiago-Pérez S., Morales-de la Garza E. (2005). Spatial trends in the geochemical composition of sediments in the Pánuco River discharge area, Gulf of Mexico. Environ. Geol. 48, 496-506. https://doi.org/10.1007/s00254-005$1300-8$

Rosales-Hoz L., Carranza-Edwards A. and Celis-Hernández O. (2007). Environmental implications of heavy metals in surface sediments near Isla de Sacrificios, Mexico. Bull. Environ. Contam. Toxicol. 78, 353-357. https://doi.org/10.1007/s00128-007-9125-7

Rosales-Hoz L., Kasper-Zubillaga J.J., Carranza-Edwards A. and Celis-Hernández O. (2008). Geochemical composition of surface sediments near Isla de Sacrificios coral reef ecosystem, Veracruz, Mexico. Hidrobiológica 18, 155-165. https://hidrobiologica.izt.uam. mx/index.php/revHidro/article/view/896

Rosales-Hoz L., Carranza-Edwards A., Sanvicente-Añorve L., Alatorre-Mendieta M.A. and Rivera-Ramírez F. (2009). Distribution of dissolved trace metals around the Sacrificios coral reef island, in the Southwestern Gulf of Mexico. Bull. Environ. Contam. Toxicol. 83, 713-719. https://doi.org/10.1007/s00128-009-9813-6

Rosales-Hoz L., Carranza-Edwards A., Martínez-Serrano R.G., Alatorre M.A. and Armstrong-Altrin J.S. (2015). Textural and geochemical characteristics of marine sediments in the SW Gulf of Mexico: Implications for source and seasonal change. Environ. Monit. Assess. 187, 205. https://doi.org/10.1007/s10661-015-4423-8

Ruiz-Fernández A.C., Sánchez-Cabeza J.A., AlonsoHernández C., Martínez-Herrera V., Pérez-Bernal L.H., Preda M., Hillaire-Marcel C., Gastaud J. and QuejidoCabezas A.J. (2012). Effects of land use change and sediment mobilization on coastal contamination (Coatzacoalcos River, Mexico). Cont. Shelf. Res. 37, 57-65. https://doi.org/10.1016/j.csr.2012.02.005

Ruiz-Fernández A.C., Sánchez-Cabeza J.A., Pérez-Bernal L.H. and Gracia A. (2019). Spatial and temporal distribution of heavy metal concentrations and enrichment in the southern Gulf of Mexico. Sci. Total 
Environ. 651, 3174-3186. https://doi.org/10.1016/j. scitotenv.2018.10.109

Salas-Monreal D., Valle-Levinson A. and Athie G. (2019). Flow modifications over a tropical coral reef system. Estuar. Coast. Shelf Sci. 217, 271-280. https://doi. org/10.1016/j.ecss.2018.11.029

Schaaf P. and Carrasco-Núñez G. (2010). Geochemical and isotopic profile of Pico de Orizaba (Citlaltépetl) volcano, Mexico: Insights for magma generation processes. J. Volcanol. Geotherm. Res. 197, 108-122. https://doi.org/10.1016/j.jvolgeores.2010.02.016

SCT (2016). Programa maestro de desarrollo portuario del Puerto de Veracruz 2016-2021. Coordinación General de Puertos y Marina Mercante, Secretaría de Comunicaciones y Transportes, Mexico, $76 \mathrm{pp}$.

Self R.P. (1977). Longshore variation in beach sands Nautla area, Veracruz, Mexico. J. Sediment. Petrol. 47, 1437-1443. https://doi.org/10.1306/212F7388-2B2411D7-8648000102C1865D

SEMARNAT (2002). Norma Oficial Mexicana NOM021-SEMARNAT-2000. Norma que establece las especificaciones de fertilidad, salinidad y clasificación de suelos, estudio, muestreo y análisis. Diario Oficial de la Federación, 31 de diciembre.

Sheldrick B.H. and Wang C. (1993). Particle size distribution. In: Soil sampling and methods of analysis (Carter M.R., Ed.). Canadian Society of Soil Science-Lewis Publishers, Boca Raton, FL, USA, 499-511.

Shepard F.P. (1954). Nomenclature based on sandsilt-clay ratios. J. Sedim. Petrol. 24, 151-158. https://doi.org/10.1306/D4269774-2B26-11D78648000102C1865D

Soon Y.K. and Abboud S. (1993). Cadmium, chromium, lead and nickel. In: Soil sampling and methods of analysis (Carter M.R., Ed.). Canadian Society of Soil Science-Lewis Publishers, Boca Raton, FL, USA, 101-108.

Taylor S. R. and McLennan S.M. (1995). The geochemical evolution of the continental crust. Reviews Geophysics 33(2), 241-265. https://doi.org/10.1029/95RG00262
Tessier A., Campbell P.G.C. and Bisson M. (1979). Sequential extraction procedure for the speciation particulate trace metals. Anal. Chem. 51, 844-851. https:// doi.org/10.1021/ac50043a017

Tessier A. and Campbell P.G.C. (1987). Partitioning of trace metals in sediments: Relationships with bioavailability. Hydrobiologia 149, 43-52. https://doi. org/10.1007/BF00048645

Tunell J.W. (1992). Natural versus human impacts to Southern Gulf of México coral reef resources. Proceedings of the Seventh International Coral Reef Symposium, Guam, 300-306.

Tunnell J.W. 2007. Reef distribution. In: Coral reefs of the Southern Gulf of Mexico (Tunnell J.W., Chávez E.A. and Whithers K., Eds.). Texas A\&M University Press, College Station, Texas, USA, 14-22.

Vázquez G.F., Sharma V.K. and Pérez-Cruz L. (2002). Concentrations of elements and metals in sediments of the southeastern Gulf of Mexico. Environ. Geol. 42, 41-46. https://doi.org/10.1007/s00254-001-0522-7

Villanueva S. and Botello A.V. (1992). Metales pesados en la zona costera del Golfo de México y Caribe Mexicano: una revisión. Rev. Int. Contam. Amb. 8, 47-61.

Walkley A. and Black I.A. (1934). An examination of Degtjareff method for determining soil organic matter and a proposed modification of the chromic acid titration method. Soil Sci. 37, 29-38.

Walling D.E. (2006). Human impact on land-ocean sediment transfer by the world's rivers. Geomorphol. 79, 192-216. https://doi.org/10.1016/j.geomorph.2006.06.019

Wang S.-L., Xu X.-R., Sun Y.-X., Liu J.-L. and Li H.-B. (2013). Heavy metal pollution in coastal areas of South China: A review. Mar. Pollut. Bull. 76, 7-15. https:// doi.org/10.1016/j.marpolbul.2013.08.025

Zavala-Hidalgo J., Morey S.L. and O’Brien J.J. (2003). Seasonal circulation on the western shelf of the Gulf of Mexico using a high-resolution numerical model. J. Geophys. Res. 108, 1-19. https://doi. org/10.1029/2003JC001879 